$\S=-1$

\title{
Assessment of Urban Growth and Sprawl Using GIS and Remote Sensing Techniques in South Ghor Region, Al-Karak, Jordan
}

\author{
Mousa Hammad Abu Ghurah ${ }^{1,2}$, Mohd Khairul Amri Kamarudin ${ }^{1}$, Noorjima Abd Wahab ${ }^{1}$, Hafizan Juahir ${ }^{1}$, Mu- \\ hammad Barzani Gasim ${ }^{1}$, Fathurrahman Lananan ${ }^{1}$, Khairul Nizam Abdul Maulud ${ }^{3}$, Mohd Hafiz Rosli ${ }^{4}$, Ahmad \\ Shakir Mohd Saudi ${ }^{5}$, Zairi Ismael Rizman ${ }^{6}$, Mohd Saupi Mohd Zin ${ }^{1}$ \\ ${ }^{I}$ East Coast Environmental Institute (ESERI), Universiti Sultan Zainal Abidin, Gong Badak Campus, 21300 Kuala Nerus, \\ Terengganu, Malaysia \\ ${ }^{2}$ Jordan Valley Authority/Lands and Survey Department, Al-Karak City/South Ghor, Jordan \\ ${ }^{3}$ Department of Civil and Structural Engineering, Faculty of Engineering and Built Environment, Universiti Kebangsaan Malaysia \\ ${ }^{4}$ Department of Environmental Sciences, Faculty of Environmental Studies, Universiti Putra Malaysia, 43400 UPM Serdang, Selangor, \\ Malaysia \\ ${ }^{5}$ Institute of Medical Science Technology, Universiti Kuala Lumpur, 43000 Kajang, Selangor, Malaysia \\ ${ }^{6}$ Faculty of Electrical Engineering, Universiti Teknologi MARA, 23000 Dungun, Terengganu, Malaysia \\ *Corresponding authorE-mail: mkhairulamri@unisza.edu.my
}

\begin{abstract}
The land is a primary natural resource and is essential for human practice and life on earth. Improvement of land use and land cover is very much helpful to policymakers, city planners and for the sustainability of urban ecosystems. The urbanization process (urban growth and sprawl) is one of the important prime factors of land cover/use change, and it is related to the growth and increase of populations and economic activities. This study aims to assess the urban growth and sprawl in South Ghor, Jordan. Supervised classification techniques were applied for LULC classification using four Satellite images (1972, 1989, 1999 and 2016). The land was classified into four categories agricultural land, pastures and bare land, urban area and water bodies. The supervised classification techniques show that urban area and agricultural land have increased while water bodies and bare land have decreased. They also show the rapid urban growth and sprawl in the study areas.
\end{abstract}

Keywords: Urban Growth; land use and land cover; GIS; Remote Sensing; South Ghor Region Jordan.

\section{Introduction}

The land is very primary natural resource and is essential for human practice and life on earth [1]. Recently and despite its importance, people are using it randomly. At present, the increase and development in human activities and population led to increasing the demand for land resources and soil for urban, industrial, and agriculture practices [2-4]. The land cover indicates the physical features of the Earth's surface like soil, vegetation, water, hills, woods, and others [5-7]. Land use indicates changes created by anthropogenic activities [4, 8-9]. Understanding land use and land cover change are vital for determining the present scenario and for the administration of natural resources and, hence, addressing the environmental problem [10-11]. These changes in Land use/cover produced several issues like the build-up of urban heat, excess runoff and other ecological problems. Improvement of land use land cover is very much helpful to policymakers, city planner and for the sustainability of urban ecosystems [12].

The urbanization process (urban growth and sprawl) is one of the important prime factors of land cover/use change, and it is related to the growth and increase of populations and economic activities. However, it is complicated to present a particular proper descrip- tion of urban growth and sprawl that satisfies all the urban planning research community [13]. Urban growth, mainly the movement of commercial and residential land to rural regions at the periphery of town areas has long been recognized as a sign of regional economic vitality. But, its advantages were increasingly balanced beside ecosystem impacts, including degradation of water and air quality, loss of pastures land and forests, and socioeconomic influences of economic disparities, infrastructure costs, and social fragmentation. All the researchers recognized that urban environments are most active in nature [14-15].

Information that is related to the land use /land cover changes and urban growth studies is very beneficial to urban planners, local government and decision makers in order to inform plans on sustainable development in the future of each area [16]. The urban sprawl extension in the indefinite landscape time describes the urban sprawl as a pattern, whereas the change of urban sprawl patterns in a landscape in various time periods describes the urban sprawl as a process [17]. However, both definitions of urban sprawl process and urban sprawl pattern can be involved in one phrase "urban sprawl" [18]. Moreover, the uncontrolled and dispersed population growth is considered as the significant factor of urban sprawl and most of the urban spatial problems [19-20]. 
Nowadays, urban sprawl is being introduced as one of the crucial urban development processes. The case of urban development has an extensive range of concepts and combines the general and comprehensive processes. The urban development operation should be debated based on its historical events and active factors such as economic and social factors over time. During the previous two centuries, we observed the expansion of huge cities and the growth of the area under their spatial impact. This operation in many homelands has been this trend: the change in the pattern of life of inhabitants caused the development of new urban regions [21].

The geographic information system and remote sensing technique make it possible to study the change in LULC [22]. The data records that are based on remote sensing records data might be useful and valuable especially in developing countries where up-to-date and dependable spatial information is lacking [23]. In previous years, records from remote sensing satellites have become active in the earth's features for mapping and presenting accurate report about LULC features [24-25]. Geographic Information System techniques (GIS) presents suitable methods of analysis of the land use/land cover issues, with tools for modeling made possible by Gis, in addition to and land use planning to study the changes in land cover with low cost, less time and better accuracy [26-27]. Interpretation of satellite data facilitates the useful estimation of water resources, water cultivation, land degradation, forestry, geomorphological conditions and other issues correlated to the environment and climate change [28-29]. The Remote sensing techniques combined with Geographic Information System (GIS) have been accepted as active and powerful tools for discovering the spatial and temporal changes of the earth's features at various scales [30-32].

Hence, in the current scenario, it has become necessary to integrate remote sensing and GIS techniques into management and urban planning. The patterns of urban sprawl over separate time periods can be systematically observed, mapped and accurately evaluated from satellite data with conventional ground data and proper image processing techniques [33-34].

Recently, studies on urban growth and expansion have been done by several scholars, mainly by using GIS and remote sensing techniques. In [42] studied the urban land expansion and environmental changes using GIS and remote sensing techniques that have occupied central place in China for the last decades, owing to rapid urbanization. In [35] examined the urban growth of Iranian cities. A Shannon's entropy calculations and post-classification method were adopted [18] with a supervised classification by using maximum likelihood method [35]. In [36] have used various Landsat images of different time periods $(1975,1989$ and 2000) and Shannon Entropy Approach for Assessment of Urban Growth in Jaipur, INDIA [36]. In [42] have simulated the urban growth according to statistics taken out by three land use maps of the Kathmandu City by using GIS. According to them, land use measurements and transition matrices are essential information to examine the changes in land use. Remote sensing techniques and GIS have been used by [43], in the Bir El Djir Municipality, east of Oran, Algeria for evaluating the urban expansion and land use land cover changes during the period 1987 to 2014.

In [37] have evaluated urban expansion and land change of Shijiazhuang, China. It used the survey of China's topographic map of the year 1981, multi-temporal city maps and two scenes of satellite multi-spectral images for evaluating the temporal and spatial characteristics of urban expansion from 1934 to 2001 and the land use/land cover change between 1987 and 2001. In [13] have carried out a study on the patterns of urban developments of the capital of Libya, Tripoli. Based on Four satellite imageries, population censuses and Shannon's entropy technique from 1986 to 2010 a period covering 26 years, they found that the urban area has largely increased with urban sprawl due to the uncontrolled population growth and construction of new buildings in agricultural and vegetation lands. In [38] carried out a study for the assessment of urban sprawl in Karachi town, Pakistan. They noted that the Karachi city had experienced meaningful changes during 1991 to 2000. The analysis also displayed that changes in the urban pattern have resulted in the loss of forest area, open areas, etc. In [44] presented an integrated method of remote sensing and GIS techniques for analysis of urban sprawl Pattern in Tiruchirappalli district, Tamil Nadu State.

In India, between the year 1998 and 2009, in [47] have used recent and readily available satellite data of IRS LISS III (2000, 2006 and 2009) and Google's earth image for evaluating the urban growth and their spatial changes during the last decade of Davanagere city in Karnataka State, India. In [45] have carried out a study to evaluate land use/land cover changes and urban development in Bangladesh capital, Dhaka between 1975 and 2003 using socio-economic data and satellite images.

In [39] have carried out a study to monitor urban expansion in the Jordan capital, Amman. Remote sensing and geographic information systems techniques (GIS) have been utilized to examine the impacts of urbanization on arable lands and to quantify the urban extension of Amman area; the study revealed that the urban area was expanded by $162 \mathrm{~km}^{2}$ over the years $1918-2002$, which represents 509 times the previous urban area.

In [40] have carried out a study to evaluate the urban expansion in Jordanian cities. Remote sensing and GIS techniques were utilized in this task to determine and estimate the development of urban spaces in three Jordanian towns: Amman, Madaba and Irbid. The study showed that the rapid urbanization and industrialization process has caused not only social problems but also environmental and socioeconomic problems in Jordanian cities. A survey carried out by [46] on the city of Irbid, Jordan evaluated the influence of contemporary urbanization on the destruction and degradation of the city's heritage. It used spatial analysis methods in GIS, e.g., 3D modeling, which focused on evaluating the modern shape of the urban way close to features of heritage. In [48] have carried out a study to examine the urban increase vis-a-vis, social factors and contemporary urban planning matters the city of Amman, Jordan. However, little studies have assessed and examined the urban growth and sprawl of Jordan [41]. The main objective of this study is to analyze and assess the urban growth and sprawl, and its patterns in south Ghor, Al-Karak province, Jordan from 1972 to 2016 using GIS and remote sensing techniques. Mainly, this study examines and assesses the urban development and sprawl occurring in south Ghor, according to an analysis of the relationship between population growth and urban development.

\section{Materials and Methods}

\subsection{Study Area}

The study area, South Ghor regions, Al-Karak province, Jordan extends approximately between $31^{\circ} 00^{\prime}-31^{\circ} 25^{\prime} \mathrm{N}$ and $35^{\circ} 25^{\prime}$ $35^{\circ} 35^{\prime} \mathrm{E}$ (Figure 1), in south Jordan along the JordanianPalestinian border. The climate of south Ghor regions is dry, with hot summers and moderate winters. The summit temperature reaches $48^{\circ} \mathrm{C}$ in the summer, while the winter temperature is 20 $25{ }^{\circ} \mathrm{C}$. The topography of south Ghor is flat, with a lot of mountains that surround it from the east side (Jordanian side) and west side (Palestinian side) with small to medium sized hills. South Ghor has a lot of scope for development and urban growth. South Ghor has a population of about sixty thousand; with population growth is relatively high within the region. Many pastures and bare lands have become urban and it is even expected that this change would continue to increase. 


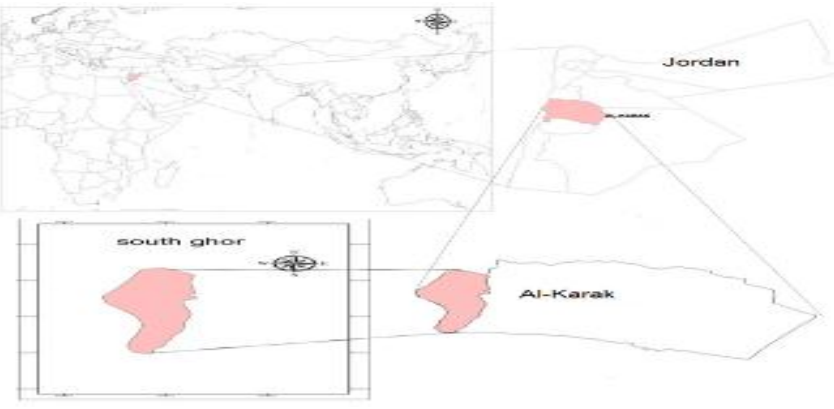

Fig. 1: Study area in South Ghor region, Al-Karak, Jordan

\subsection{Database Design}

Sets of multi-temporal and spectral remote sensing images were classified to determine the land use/land cover changes and the urban growth of South Ghor area. Four satellite images were acquired in 1972, 1989, 1999 and 2016 respectively. The images were in the same vegetation season with a cloud cover of $0 \%$. Moreover, data such as population's census and topographic maps were utilized for referencing purposes and for analysis. The images have a spatial resolution $30 \mathrm{~m}$ so that their spatial resolution matches the smallest resolution imagery. Various techniques were utilized to solve a few problems in the images, which contained some distortions. Details of the supporting data and remote sensing data are shown in Table 1. To produce various thematic map layers, like, Al-Karak administrative boundary map, roads and administrative boundary map using the topo-sheets and other available maps ArcGIS software (ESRI) were used.

Table 1: Data used in the study

\begin{tabular}{|c|c|c|}
\hline Satellite images & Resolution & Year \\
\hline Landsat TM & 30 & 1972 \\
\hline Landsat TM & 30 & 1989 \\
\hline Landsat TM & 30 & 1999 \\
\hline Landsat TM, ETM & 30 & 2016 \\
\hline \multicolumn{3}{|c|}{$\begin{array}{l}\text { Supporting data } \\
\end{array}$} \\
\hline Topographic map & $1: 25,000$ & \\
\hline Supporting Jordanian censuses & & 1972 to 2016 \\
\hline
\end{tabular}

\subsection{Methodology}

The methodology procedures include four prime steps. The first step is image processing through enhancement and georeferencing. The second step is to define the current land use/land cover categories, and the third step is to classify images under supervised classification techniques by using maximum likelihood method. The last step is to study the direction and extent of urban growth from the period 1972 to 2016. Finally, relative and absolute Shannon's entropy approach was applied to recognize the urban growth patterns in the study region. Furthermore, the change percentage of Shannon's entropy values was measured to understand the urban sprawl process.

\section{Results and Discussion}

\subsection{Land Use/Cover Changes}

Four land use/land cover categories provided by the classifications method in the study region, agricultural land, pastures and bare land, urban area and water bodies. Table 5-7 and Figure 5-7 include data that shows that both adverse and positive changes occurred in the land use/cover types of the South Ghor region. During the last four decades, the pastures and bare land have reduced from $53.60 \%$ (20072.2) hectares in 1972 to $50.22 \%$ (18806.1) hectares in 1989 to $44.67 \%$ (16728.7) in 1999 to (16761.4) in 2016 which accounts for $44.76 \%$ of the total area in the study region. The urban area has increased from $0.77 \%$ (289.8) hectares in 1972 to $1.38 \%$ (515.7) hectares in 1989 to $2.96 \%$ (1107.99) hectares in 1999 to (1802.52) hectares in 2016 which accounts for $(4.81 \%)$.

The agricultural areas in the study region have expanded from $3.30 \%$ (1239.12) hectares in 1972 to $8.94 \%$ (3347.82) hectares in 1989 to $10.78 \%$ (4033.35) hectares in 1999 to (4765.86) hectares in 2016, which accounts for $(12.73 \%)$ of the total area in the study region. The water bodies of the study area have changed from $42.31 \%$ ( 15842.5 ) hectares in 1972 to $39.46 \%$ (14776.7) hectares in 1989 to $41.60 \%$ (15576.7) hectares in 1999 to (14116.9) hectares in 2016 which accounts for $(37.70 \%)$ of the total area in the study region. These figures and tables reveal the changes for the various land categories in south Ghor region through the last four decades.

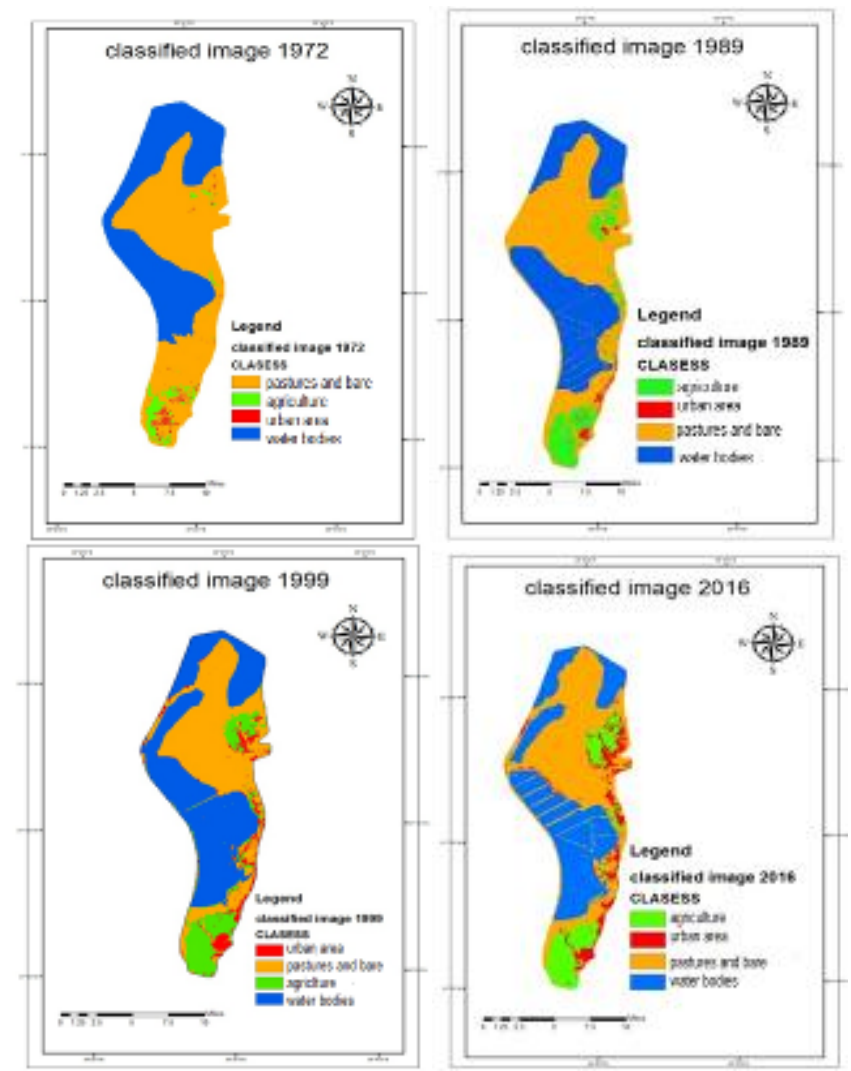

Fig. 2: Multi-temporal images classification for years 1972, 1989, 1999 and 2016 in South Ghor, Jordan

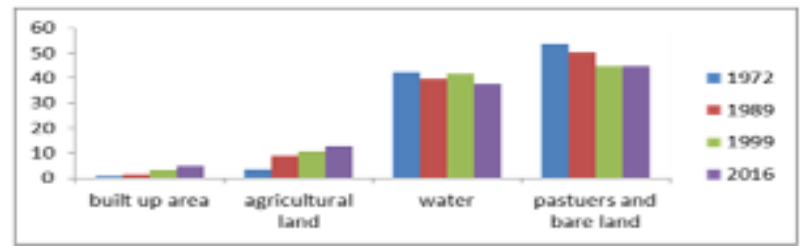

Fig. 3: Diagram for the rate change (\%) and by hectares at every study period

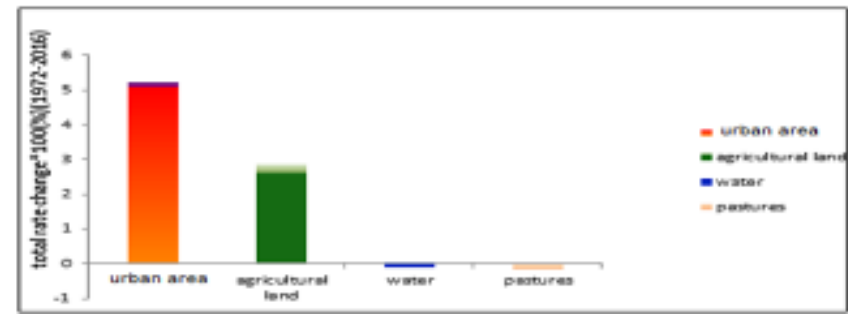

Fig. 4: Rate change $*(100 \%)$ at every study period for every class according to origin area for each class 
Table 2: Area change and rate by hectares at every study period

\begin{tabular}{|c|c|c|c|c|c|c|c|c|c|c|}
\hline & \multicolumn{2}{|c|}{1972} & \multicolumn{2}{|c|}{1989} & \multicolumn{2}{|c|}{1999} & \multicolumn{2}{|c|}{2016} & \multicolumn{2}{|c|}{ Total change 1972-2016 } \\
\hline & Area & Rate & Area & Rate & Area & Rate & Area & Rate & Area & Rate \\
\hline Urban area (hec) & 289.8 & 0.77 & 515.7 & 1.38 & 1107.9 & 2.96 & 1802.5 & 4.81 & 1512.72 & 4.04 \\
\hline Agricultural land & 1239.12 & 3.3 & 33478.2 & 8.94 & 40333.5 & 10.78 & 4765.86 & 12.73 & 3526.74 & 9.42 \\
\hline Water bodies & 15842.5 & 42.31 & 14776.7 & 39.46 & 15576.7 & 41.60 & 14116.9 & 37.70 & 1725.76 & 4.61 \\
\hline Pastures and bare land & 20075.2 & 53.6 & 18806.1 & 50.22 & 16728.7 & 44.67 & 16761.4 & 44.76 & 3313.80 & 8.85 \\
\hline
\end{tabular}

Table 3: Rate change $*(100 \%)$ at every study period for every class according to origin area for each class

\begin{tabular}{|c|c|c|c|c|}
\hline & Rate Change 1972-1989 & Rate Change 1989-1999 & Rate Change 1999-2016 & Total Change 1972-2016 \\
\hline Urban area (hec) & 0.78 & 1.15 & 0.63 \\
\hline Agricultural land & 1.70 & 0.20 & 0.18 \\
\hline Water bodies & -0.07 & 0.05 & -0.10 \\
\hline Pastures and bare land & -0.06 & -0.11 & -0.11 \\
\hline
\end{tabular}

\subsection{Urban Growth and Expansion in South Ghor}

The interpretation of the classified images showed in Figure 2, 5 and 6 , the dispersion of urban sprawl, the urban development pattern of each district, the range of urban regions, and so on, can be determined and noticed easily. The classification outcomes presented simplified, clear and accurate optical maps of the South Ghor region, which looked like a meaningful indication of urban sprawl patterns and urban range.

Over the past 40 years, the urban growth and expansion process of South Ghor experienced some of the very crucial changes and evolution.

The results prove that there is a remarkable massive concentration scale of urban areas in the regions of South Ghor. Additionally, the areas of urban lands were estimated for each study periods by classified images shown in Figure 2, 5 and 6.

The results revealed the concentration of urban areas at every period. The new urban expansion and sprawl concentrated around the main transportation routes and water resources in the South Ghor regions.

Then it began to get the other directions to different parts of the region transportation routes and water resources in the south Ghor regions. Then it began to get to the other directions and to different parts of the region.

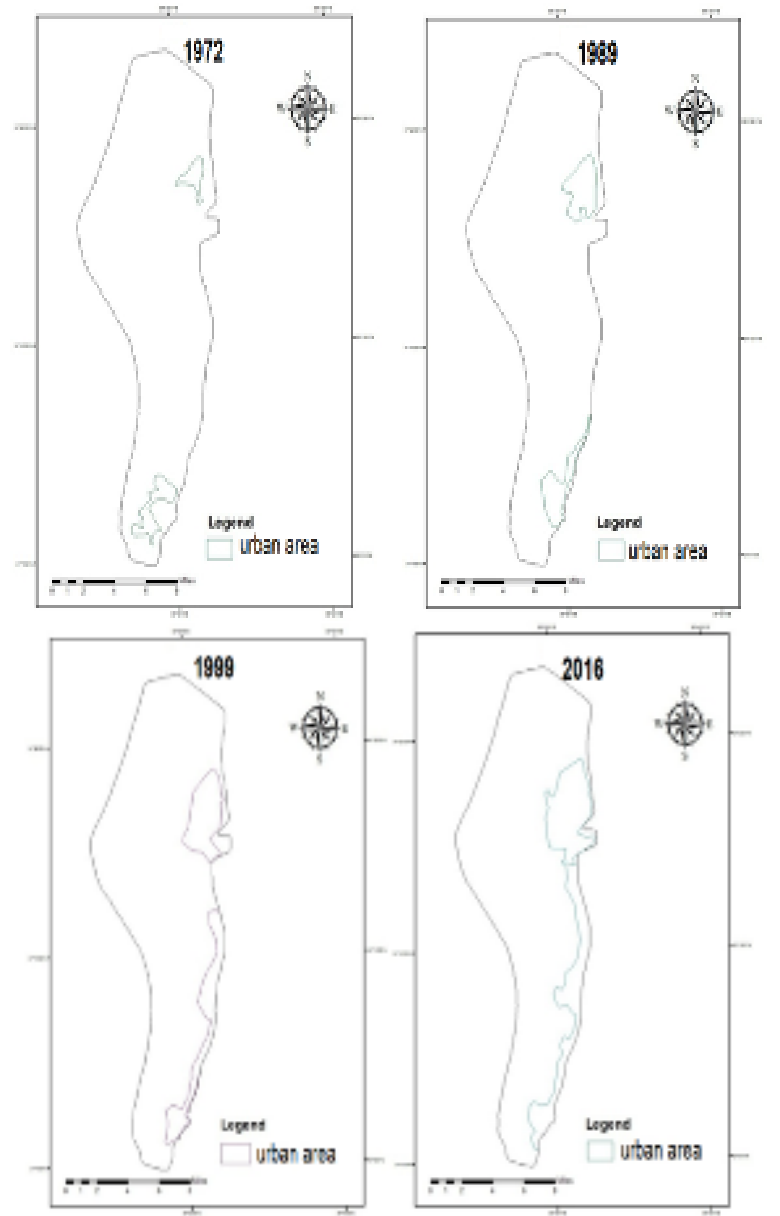

Fig. 5: Trends of the urban growth and expansion in South Ghor every study period

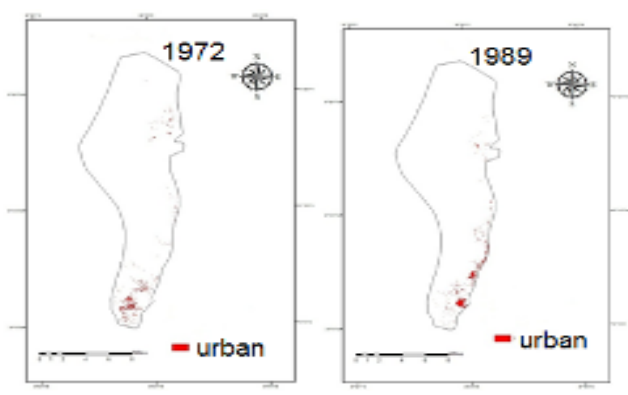




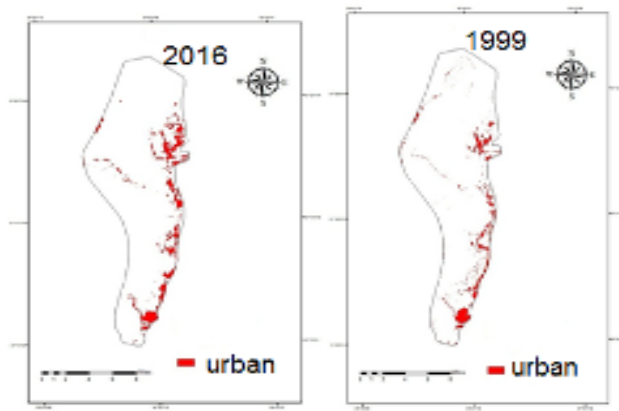

Fig. 6: Trends of south Ghor urban Growth and sprawl in the period from 1972s to 2016

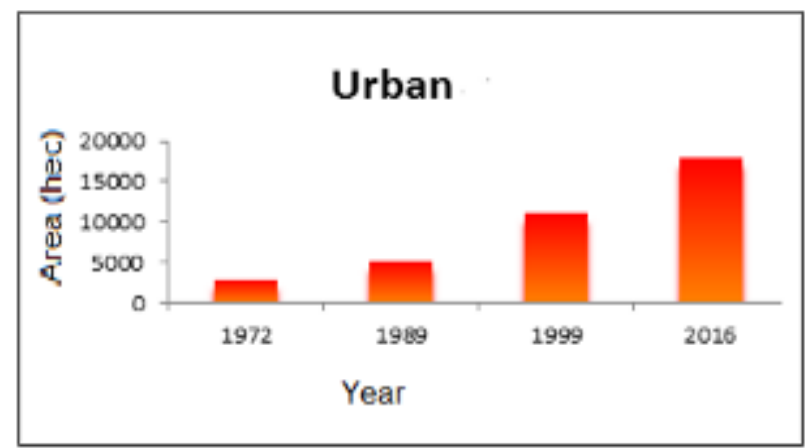

Fig. 7: Development of South Ghor urban area (hec) from 1972 to 2016

\subsection{Urban Area and Population Growth}

The population data in Table 4 show that high population growth in South Ghor that appears between 1972 and 2016. The principal reasons are ascribed to the large increase in birth rates, migration flows to South Ghor from other regions.

The urban growth and sprawl resulted from the hurried growth of the population in South Ghor. Census data indicate that the population of South Ghor stood at 13843 in 1979. Now, it has reached 61121in 2016 with an annual growth rate of 9.32\% during 19792016. Reasonably, this growth in the population of South Ghor has contributed to increasing pressure on the area's poor resources and to the socioeconomic development of urban areas. Table 5 obviously shows that the increase is absolutely related to population growth.

Table 4: Population and number of buildings in south Ghor at different periods

\begin{tabular}{|c|c|c|}
\hline Year & Population & Buildings \\
\hline 1972 & 6120 & 1221 \\
\hline 1980 & 13843 & 2308 \\
\hline 1989 & 21787 & 3633 \\
\hline 1999 & 30557 & 5150 \\
\hline 2010 & 43733 & 10273 \\
\hline 2016 & 61121 & 17920 \\
\hline
\end{tabular}

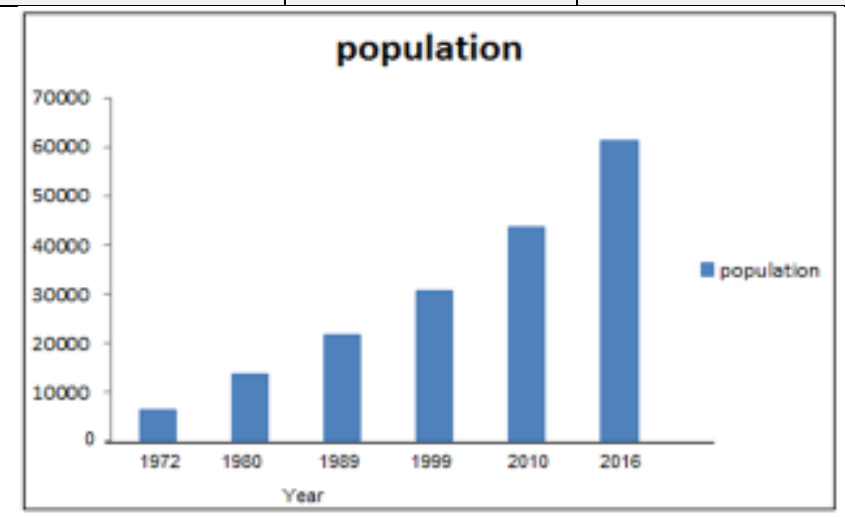

Fig. 8: Growth of South Ghor population in the period from 1972 to 2016

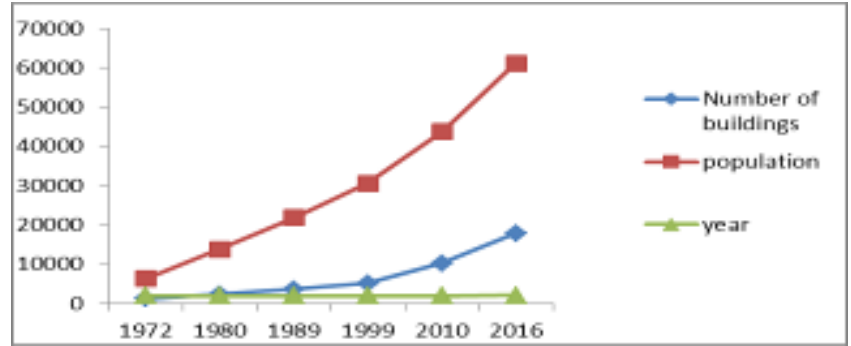

Fig. 9: A historical description of the relationship between population growth and the number of buildings during the study period of south Ghor

\subsection{Shannon's Entropy and Urban Areas}

Shannon's entropy is a known technique that is used as a sign of spatial dispersion, or concentration of urban area to a reference point; it can utilize several geographical variables. The method may show the trends and shape of spatial patterns; it is also an acceptable method, as it can be used to measure several spatial variables at GIS [49-50].

The entropy calculation considers that urban land is a divide in $n$ zones and a variable $\mathrm{X}$ gets on a value $\mathrm{Xi}$ for any zone I $2\{1$, $2, \ldots, \mathrm{n}\}$. Shannon's entropy computed as:

$H_{n}=\sum_{i}^{n} P_{i} \log \left(\frac{1}{p_{i}}\right)$

Pi hither is the proportion or probability of the variable in i zone and is given by:

$P_{i}=\frac{X_{i}}{\sum_{k}^{n} X_{k}}$

The value of entropy Shannon ranges among zero, for a completely concentrated distribution, and $\log (\mathrm{n})$, for a completely dispersed distribution of X. Equation (1) represents what is understood as absolute entropy. For the objective of such a study, zones are described as concentric spheres around the selected crossing of roads or around the area study center [50].

One can also apply the relative entropy including rates varying between 1 for total dispersion and 0 for complete concentration. Relative entropy as:

$H_{n}=\sum_{i}^{n} P_{\bar{i}} \log \left(\frac{1}{P_{\bar{i}}}\right) / \log (n)$

Table 5: Shannon entropy values in south Ghor at different periods

\begin{tabular}{|c|c|}
\hline Year & Relative Entropy Value \\
\hline 1972 & 0.43 \\
\hline 1989 & 0.47 \\
\hline 1999 & 0.51 \\
\hline 2016 & 0.54 \\
\hline
\end{tabular}

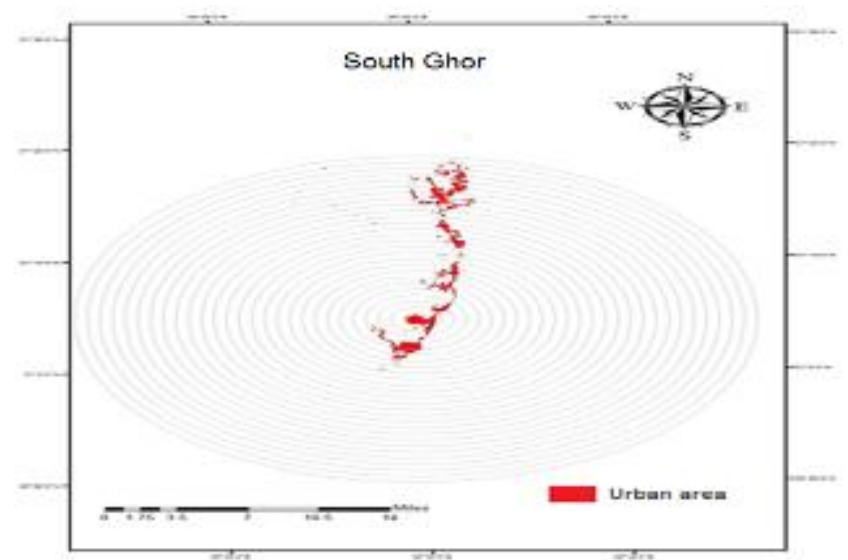

Fig. 10: Buffers drawn to calculate Shannon's Entropy in South Ghor using the classified data 


\section{Conclusion}

South Ghor regions started from a small area near Al-Karak city to a large center. This led to several notable changes in the land use/land cover pattern. Urban development is taking place in all directions especially, with local roads being built to transport people from one area to another. According to Jordan valley authority reports, a lot of residential and industrial projects have developed in the south of Ghor during the last years that have absorbed several hundred hectares of land. Recently, the northern and southern part of south Ghor is rapidly transforming into residential settlements.

The study concludes that there is a notable and significant development in urban spaces that have transferred from 289.8 hectares in 1972 to 1512.72 hectares in 2016 . The primary cause of the increase in urbanization is attributed to the rapid growth of the population of south Ghor, which reached 61123 in 2016 from 6120 in 1972. Up to date, the region of south Ghor is developing rapidly in terms of infrastructure projects, commercial areas, residential areas as well as industrial expansion. Its population is increasing, outside and within the region's boundaries.

The expansion of new residential structures led to de-shaping the structural pattern of the region. This obviously reflects the richness of south Ghor with regards to the urban area, which has recently reached the phase of urban sprawl. Consequently, this poses significant challenges on public and privet authorities when providing services to the population, particularly those associated with the services sector, by way of example, water control, water supply and distribution; are under severe pressure. This reveals a terrible situation for local government, urban planners and decision makers alike. Dynamic planning and proper control of environmental practices is an essential need; otherwise, urban development problems may complicate further shortly.

\section{Acknowledgement}

The authors acknowledge to UniSZA for Scholarship under research grants: UniSZA/2017/SRGS/17) - R0019-R017. Special thanks are also dedicated to East Cost Environmental Research Institute (ESERI) for the support, advice and guidance for this study.

\section{References}

[1] Molla. M. B. (2015). Land Use/Land Cover Dynamics in the Central Rift Valley Region of Ethiopia: Case of Arsi Negele District. African Journal of Agricultural Research, 10(5), 434-449

[2] Toriman, M. E., Gasim, M. B., Yusop, Z., Shahid, I., Mastura, S. A. S., Abdullah, P., Jaafar, M., Aziz, N. A. A., Kamarudin, M. K. A., Jaafar, O., Karim, O., Juahir, H., Jamil, N. R. (2012). Use of $137^{\text {Cs }}$ activity to investigate sediment movement and transport modeling in river coastal environment. American Journal of Environmental Sciences, 8(4), 417-423.

[3] Amri Kamarudin, M. K., Idris, M., Toriman, M. E. (2013). Analysis of Leptobarbus hoevenii in control environment at natural lake. American Journal of Agricultural and Biological Science, 8(2), $142-148$

[4] Abdullah, N. M., Toriman, M. E., Din, H. M., Aziz, N. A. A., Kamarudin, M. K. A., Rani, N. S. A., Ata, F. M., Saad, M. H., Abdullah, N. W., Idris, M., Jamil, N. R. (2013). Influence of Spatial and Temporal Factors in Determining Rainfall Interception at Dipterocarp Forest Canopy, Lake Chini, Pahang. Malaysian Journal of Analytical Sciences, 17(1), 11-23.

[5] Toriman, M. E., At, F. M., Kamarudin, M. K. A., Idris, M. (2015) Bed-load sediment profile and effect of river bank erosion on river cross-section. American Journal of Environmental Sciences, 9(4), 292-300.

[6] Din, H. M., Toriman, M. E., Mokhtar, M., Elfithri, R., Aziz, N. A. A., Abdullah, N. M., Kamarudin, M. K. A. (2012). Loading concentrations of pollutant in Alur Ilmu at UKM Bangi campus: Event mean concentration (EMC) approach. Malaysian Journal of Analytical Sciences, 16(3), 353-365.
[7] Samal, D. R., Gedam S. S. (2016). Monitoring land use changes associated with urbanization: An object based Image analysis European Journal of Remote Sensing, 48, 85-99.

[8] Ali, M., Nadaoka, K., Negm, A., Iskander, M. (2015). Detection of Shoreline and Land Cover Changes around Rosetta Promontory, Egypt, Based on Remote Sensing Analysis. Land, 4, 216-230.

[9] Wahab, N. A., Kamarudin, M. K. A., Gasim, M. B., Umar, R. Ata, F. M., Sulaiman, N. H. (2016). Assessment of total suspended sediment and bed sediment grains in upstream areas of Lata Berangin, Terengganu. International Journal on Advanced Science, Engineering and Information Technology, 6(5), 757-763.

[10] Jaafar, O., Toriman, M. E. H., Idris, M. H., Sharifah Mastura, S. A., Juahir, H. H., Aziz, N. A. A., Kamarudin, K. A., Jamil, N. R. (2010). Study of water level-discharge relationship using Artificial Neural Network (ANN) in Sungai Gumum, Tasik Chini Pahang Malaysia. Research Journal of Applied Sciences, 5(1), 20-26.

[11] Kamaruddin, A. F., Toriman, M. E., Juahir, H., Zain, S. M., Rahman, M. N. A., Amri Kamarudin, M. K., Azid, A. (2015). Spatial characterization and identification sources of pollution using multivariate analysis at Terengganu River Basin, Malaysia. Jurnal Teknologi, 77(1), 269-273.

[12] Hassan, A. M., Lee, H. (2015). Toward the sustainable development of urban areas: An overview of global trends in trials and policies. Land Use Policy, 48, 199-212.

[13] Al-Sharif, A. A., Pradhan, B., Shafri, H. Z. M., Mansor, S. (2013). Spatio-temporal analysis of urban and population growths in Tripoli using remotely sensed data and GIS. Indian Journal of Science and Technology, 6(8), 5134-5142.

[14] Kamarudin, M. K. A., Toriman, M. E., Wahab, N. A., Hafizan, J., Endut, A., Umar, R., Gasim, M. B. (2017). Development of Stream Classification System on Tropical Areas with Statistical Approval in Pahang River Basin, Malaysia. Desalination and water Treatment, 96, 237-254.

[15] Gasim, M. B., Toriman, M. E., Idris, M., Lun, P. I., Kamarudin, M. K. A., Nor Azlina, A. A., Mokhtar, M., Mastura, S. A. S. (2013) River flow conditions and dynamic state analysis of Pahang River. American Journal of Applied Sciences, 10(1), 42-57.

[16] Sundara Kumar, K., Harika, M., Begum, S. A., Yamini, S., Balakrishna, K. (2012). Land use and land cover change detection and urban sprawl analysis of Vijayawada city using multitemporal landsat data. International Journal of Engineering Science and Technology, 4(01), 170-178.

[17] Bhatta, B., Saraswati, S., Bandyopadhyay, D. (2010). Urban sprawl measurement from remote sensing data. Applied Geography, 30(4), 731-740.

[18] Sarvestani, M. S., Ibrahim, A. L. (2011). Three decades of urban growth in the city of Shiraz, Iran: A remote sensing and geographic information systems application, 28(4), 320-329.

[19] Toriman, M. E., Abdullah, S. N. F., Azizan, I. A., Kamarudin, M. K A., Umar, R., Mohamad, N. (2015). Spatial and temporal assessment on drug addiction using multivariate analysis and GIS. Malaysian Journal of Analytical Sciences, 19(6), 1361-1373.

[20] Bhatta, B. (2009). Analysis of urban growth pattern using remote sensing and GIS: a case study of Kolkata, India. International Journal of Remote Sensing, 30(18), 4733-4746.

[21] Dadras, M., Shafri, H. Z. M., Ahmad, N., Pradhan, B., Safarpour, S. (2014). Six decades of urban growth using remote sensing and GIS in the city of Bandar Abbas, Iran. In IOP Conference Series: Earth and Environmental Science, 20(1), 012007. IOP Publishing.

[22] Talha, A. M., Javed, A., Khanday, M. Y. (2014) Spatio-Temporal Land Cover Analysis in Makhawan Watershed (M.P.), India through Remote Sensing and GIS Techniques", Journal of Geographic Information System, 6, 298- 306.

[23] Pradeep, C, Bharadwaj, A. K, Thirumalaivasan, D. (2014). Land use and land cover change detection through remote sensing approach: A case study of Kodaikanal taluk, Tamil nadu, International Journal of Geomatics and Geosciences, 4(4), 600-612.

[24] Yuan, F. (2007). Urban expansion and its environmental impact analysis using high resolution remote sensing data: A case study in the Greater Mankato Area. In ASPRS 2007 Annum Conference Tampa, Florida.

[25] Harshika A. K., Sopan I. (2012) Land Use Land Cover Classification and Change Detection Using High Resolution Temporal Satellite Data. Journal of Environment, 1(4), 146-15.

[26] Kamarudin, M. K. A., Toriman, M. E., Juahir, H., Azid, A., Gasim, M. B., Saudi, A. S. M., Umar, R., Sulaiman, N. H., Ata, F. M., Mustafa, A. D., Amran, M. A., Yusoff, W. A., Azaman, F. (2015b). Assessment of river plan change using RS and GIS technique. Jurnal Teknologi, 76(1), 31-38. 
[27] Selvam, S., Magesh, S. N., Chidambaram, S., Rajamanickam M. Sashikkuma, C. M. (2016). A GIS based identification of groundwater recharge potential zones using RS and IF technique: A case study in Ottapidaram taluk, Tuticorin district, Tamil Nadu. Environ Earth Sci., 73, 3785-3799.

[28] Tarun K., Jhariya, D. C. (2015) Land quality index assessment for agricultural purpose using multi-criteria decision analysis (MCDA), Geocarto International, 30(7), 822-841.

[29] Khan, R., \& Jhariya, D. C. (2016). Land Use Land Cover Change Detection Using Remote Sensing and Geographic Information System in Raipur Municipal Corporation Area, Chhattisgarh. SSARSC International Journal of Geo Science and Geo Informatics, 3(1), 1-4.

[30] Amici, Valerio, Duccio R., Goffredo F., Giovanni B., Elisa S., Francesco G., Sara L., Anna S., Alessandro C. (2015). Landscape structure effects on forest plant diversity at local scale: exploring the role of spatial extent. Ecological complexity, 21, 44-52.

[31] Serra, P., Pons, X., \& Saurí, D. (2008). Land-cover and land-use change in a Mediterranean landscape: a spatial analysis of driving forces integrating biophysical and human factors. Applied Geography, 28(3), 189-209.

[32] Makhamreha, Z., \& Almanasyeha, N. (2011). Analyzing the state and pattern of urban growth and city planning in Amman using satellite images and GIS. European Journal of Social Sciences, 24(2), 225-264.

[33] Saravanan, P., Ilangovan, P. (2010). Identication of urban sprawl pattern for Madurai region using GIS. Int. J. Geomat. Geosci, 1(2), $141-149$.

[34] Ramachandra, T. V. Jagadish, K. S. (2011) Indian Institute of Science, Bangalore Urbanisation and urban sprawl. http://wgbis.ces.iisc. ernet.in/energy/urban/chapter3.htm.

[35] Wei YD, Ye X. Urbanization, urban land expansion and environmental change in China. Stochastic environmental research and risk assessment. 2014, 28(4):757-765.

[36] Punia M, Singh L. (2011). Entropy approach for assessment of urban growth: a case study of Jaipur, India, Journal of the Indian Society of Remote Sensing, 40(2), 231-244.

[37] Xiao, J., Shen, Y., Ge, J., Tateishi, R., Tang, C., Liang, Y., Huang, Z. (2006). Evaluating urban expansion and land use change in Shijiazhuang, China, by using GIS and remote sensing. Landscape and urban planning, 75(1), 69-80.

[38] Mahboob, M. A., Atif, I., Iqbal, J. (2015). Remote sensing and GIS applications for assessment of urban sprawl in Karachi, Pakistan. Science, Technology and Development, 34(3), 179-188.

[39] Al Rawashdeh, S., Saleh, B. (2006). Satellite monitoring of urban spatial growth in the Amman area, Jordan. Journal of Urban Planning and Development, 132(4), 211-216.

[40] Saleh, B., \& Al Rawashdeh, S. (2007). Study of urban expansion in Jordanian cities using GIS and remote Sensing. International Journal of Applied Science and Engineering, 5(1): 41-52.

[41] Oroud, I. M., Al Rousan, N. M. (2004). Urban encroachment on rain-fed agricultural lands in Jordan during the second half of the 20th century. Arab World Geographer, 7: 165-180.

[42] Thapa RB, Murayama Y. Urban growth modeling of Kathmandu metropolitan region, Nepal. Computers, Environment and Urban Systems. 2011, 35(1):25-34.

[43] Smahi Z, Remaoun K, Achouri F. The Urban Expansion Characterization of the Bir El Djir Municipality Using Remote Sensing and GIS. World Academy of Science, Engineering and Technology, International Journal of Civil, Environmental, Structural, Construction and Architectural Engineering. 2015, 9(4):406-409.

[44] Radhakrishnan S, Moore CA. A source book in Indian philosophy. Princeton University Press, 2014.

[45] Dewan AM, Yamaguchi Y. Land use and land cover change in Greater Dhaka, Bangladesh: Using remote sensing to promote sustainable urbanization. Applied Geography. 2009, 29(3):390-401

[46] Al-Kheder S, Haddad N, Fakhoury L, Baqaen S. A GIS analysis of the impact of modern practices and polices on the urban heritage of Irbid, Jordan. Cities. 2009, 26(2):81-92.

[47] Vashum KT, Jayakumar S. Methods to estimate above-ground biomass and carbon stock in natural forests-A review. J. Ecosyst. Ecogr. 2012, 2(4):1-7.

[48] Potter RB, Darmame K, Barham N, Nortcliff S. "Ever-growing Amman", Jordan: Urban expansion, social polarisation and contemporary urban planning issues. Habitat international. 2009 33(1):81-92.

[49] Sudhira HS, Ramachandra TV, Jagadish KS. Urban sprawl: Metrics, dynamics and modelling using GIS. International Journal of Applied Earth Observation and Geoinformation. 2004, 5(1):29-39.
[50] Yeh AG, Li X. A constrained CA model for the simulation and planning of sustainable urban forms by using GIS. Environment and Planning B: Planning and Design. 2001, 28(5):733-53. 